[Article]

\title{
配位化合物 $\mathrm{Zn}(\mathrm{Met})_{3}\left(\mathrm{NO}_{3}\right)_{2} \cdot \mathrm{H}_{2} \mathrm{O}(\mathrm{s})$ (Met $=L-\alpha$-蛋氨酸)的 低温热容及标准摩尔生成焓
}

\author{
张国春 周春生 高胜利 ${ }^{*}$ \\ (商洛学院化学与化学工程系, 陕西商洛 726000)
}

\begin{abstract}
摘要: 利用精密绝热热量仪测定了配合化合物 $\mathrm{Zn}(\mathrm{Met})_{3}\left(\mathrm{NO}_{3}\right)_{2} \cdot \mathrm{H}_{2} \mathrm{O}(\mathrm{s})$ (Met=L- $\alpha$-蛋氨酸)在 78-371 K温区的 摩尔热容. 通过热容曲线解析, 得到了该配合物的起始脱水温度为 $T_{\mathrm{D}}=325.10 \mathrm{~K}$. 将该温区的摩尔热容实验值 用最小二乘法拟合得到了摩尔热容 $\left(C_{p}\right)$ 对约化温度 $(T)$ 的多项式方程, 由此计算得到了配合物的舒平热容值和 热力学函数值. 基于设计的热化学循环, 选择 $100 \mathrm{~mL} 2 \mathrm{~mol} \cdot \mathrm{L}^{-1} \mathrm{HCl}$ 溶液为量热溶剂, 利用等温环境溶解-反应 热量计, 得到了 $298.15 \mathrm{~K}$ 配合物的标准摩尔生成焓 $\Delta H_{\mathrm{m}}^{0}\left[\mathrm{Zn}(\mathrm{Met})_{3}\left(\mathrm{NO}_{3}\right)_{2} \cdot \mathrm{H}_{2} \mathrm{O}, \mathrm{s}\right]=-(1472.65 \pm 0.76) \mathrm{J} \cdot \mathrm{mol}^{-1}$.
\end{abstract}

关键词： 绝热量热法; 热容; 标准摩尔生成焓; 溶解-反应量热法; $\mathrm{Zn}(\mathrm{Met})_{3}\left(\mathrm{NO}_{3}\right)_{2} \cdot \mathrm{H}_{2} \mathrm{O}(\mathrm{s})$ 中图分类号: 0642.1

\section{Low Temperature Heat Capacities and Standard Molar Enthalpy of Formation of the Coordination Compound $\mathrm{Zn}(\mathrm{Met})_{3}\left(\mathrm{NO}_{3}\right)_{2} \cdot \mathrm{H}_{2} \mathrm{O}(\mathrm{s})$ (Met=L- $\alpha$-Methionine)}

\author{
ZHANG Guo-Chun ZHOU Chun-Sheng GAO Sheng-Li* \\ (Department of Chemistry \& Chemical Engineering, Shangluo University, Shangluo 726000, Shaanxi Province, P. R. China)
}

\begin{abstract}
Low temperature heat capacities of the compound $\mathrm{Zn}(\mathrm{Met})_{3}\left(\mathrm{NO}_{3}\right)_{2} \cdot \mathrm{H}_{2} \mathrm{O}(\mathrm{s})$ have been measured by a precision automated adiabatic calorimeter over the temperature range $78-371 \mathrm{~K}$. The initial dehydration temperature of the coordination compound was determined to be $T_{\mathrm{D}}=325.10 \mathrm{~K}$ by analysis of the heat-capacity curve. The experimental values of the molar heat capacities in the temperature region have been fitted to a polynomial equation of heat capacities with the reduced temperature $(X),[X=$ $f(T)$ ], by the least squares method. Smoothed heat capacities and thermodynamic functions relative to the standard reference temperature $298.15 \mathrm{~K}$ of the compound were derived from the fitted polynomial equation and listed at $5 \mathrm{~K}$ internals. Using $100 \mathrm{~mL}$ of $2 \mathrm{~mol} \cdot \mathrm{L}^{-1} \mathrm{HCl}(\mathrm{aq})$ as calorimetric solvent, with an isoperibol solution-reaction calorimeter, the standard molar enthalpy of formation of the compound was determined to be $\left.\Delta_{\mathrm{H}} \mathrm{H}_{\mathrm{m}}^{\mathrm{p}} \mathrm{Zn}(\mathrm{Met})_{3}\left(\mathrm{NO}_{3}\right)_{2} \cdot \mathrm{H}_{2} \mathrm{O}, \mathrm{s}\right]=-(1472.65 \pm 0.76) \mathrm{J} \cdot \mathrm{mol}^{-1}$ by a designed thermochemical cycle.
\end{abstract}

Key Words: Adiabatic calorimetry; Heat capacity; Standard molar enthalpy of formation; Isoperibol solution-reaction calorimetry; $\mathrm{Zn}(\mathrm{Met})_{3}\left(\mathrm{NO}_{3}\right)_{2} \cdot \mathrm{H}_{2} \mathrm{O}(\mathrm{s})$

\section{Introduction}

It is well known that zinc as one of the trace elements plays an important role in the physical growth of human beings, especially in intelligence development. Many diseases result from deficiency of zinc in the human body, such as dwarfism, hypertension, rheumatoid arthritis, sugar diabetes, and cardiovascular diseases, etc. The L- $\alpha$-amino acids are indispensable nutrients in organisms and the basic units of the proteins necessary

Received: June 12, 2013; Revised: September 9, 2013; Published on Web: September 10, 2013.

"Corresponding author. Email: gaoshli@nwu.edu.cn; Tel: +86-29-88373306.

The project was support by the National Natural Science Foundation of China $(21273171,21127004,21173168)$ and Scientific Research Program Funded by Shaanxi Provincial Education Department, China (11JK0578, 11JS110).

国家自然科学基金(21273171, 21127004, 21173168)和陕西省教育厅专项基金(11JK0578, 11JS110)资助项目

(C) Editorial office of Acta Physico-Chimica Sinica 
for life activity. Zinc compounds with $\mathrm{L}$ - $\alpha$-amino acids are considered to be one of the most efficient zinc tonics because they have a higher absorption ratio in the human body than traditionally inorganic and organic weak-acid zinc tonics. Such zinc coordination compounds showed wide applications in medicine, foodstuff, animal feed, and cosmetic as nutrient additive. ${ }^{1-3}$ Gao et al. ${ }^{4}$ has investigated the phase chemistry of the coordination behavior of zinc salts with L- $\alpha$-methionine by the method of semi-micro phase equilibrium. The corresponding equilibrium phase diagram and refractive index diagram have been constructed from the compositions of saturated solutions and the data on refractive indices in ternary systems of $\mathrm{Zn}-\mathrm{Met}-\mathrm{H}_{2} \mathrm{O}$. The compound, $\mathrm{Zn}(\mathrm{Met})_{3}\left(\mathrm{NO}_{3}\right)_{2} \cdot \mathrm{H}_{2} \mathrm{O}(\mathrm{s})$, was synthesized in water and acetone under the guidance of equilibrium phase diagram, characterized by means of Fourier transform infrared (FTIR) spectroscopy, X-ray diffraction (XRD), thermogravimetric analysis/differential thermal analysis (TG/DTA), and the initial dehydration temperature $\left(T_{\mathrm{D}}\right)$ of the solid compound was reported to be $323.15 \mathrm{~K}$ by thermogravimetry.

However, other important thermodynamic properties of the compound have not been reported in the literature so far. In continuation of our studies on the compounds of zinc with L- $\alpha$ amino acid, the low temperature heat capacities over the temperature range $78-371 \mathrm{~K}$ and the standard molar enthalpy of formation of the title compound at $T=298.15 \mathrm{~K}$ have been measured by adiabatic calorimetry and isoperibol solution-reaction calorimetry, respectively. The resulting data would provide more thermodynamic supports for the practical application of the compound.

\section{Experimental}

\subsection{Synthesis and characterization of the compound}

$\mathrm{ZnSO}_{4} \cdot 7 \mathrm{H}_{2} \mathrm{O}(\mathrm{s}), \mathrm{NaNO}_{3}(\mathrm{~s}), \mathrm{L}-\alpha$-methionine(s), $\alpha-\mathrm{Al}_{2} \mathrm{O}_{3}(\mathrm{~s})$, and $\mathrm{HCl}(\mathrm{aq})$ obtained from Shanghai Reagent Factory, China, were of analytical grade with purity prior to $99.50 \% . \mathrm{KCl}(\mathrm{s})$ with $99.90 \%$ purity as Standard Reference Material 1655 was obtained from the National Institute of Standards and Technology. The solid compound, $\mathrm{Zn}(\mathrm{Met})_{3}\left(\mathrm{NO}_{3}\right)_{2} \cdot \mathrm{H}_{2} \mathrm{O}(\mathrm{s})$ as white lumpy crystals, was prepared by a semi-micro phase equilibrium method. ${ }^{4,5}$ The solid compound obtained was kept in a desiccator containing $\mathrm{P}_{4} \mathrm{O}_{10}$. The results of chemical and elemental analyses, IR, TG/DTG, and XRD indicated that the compound was formulated as $\mathrm{Zn}(\mathrm{Met})_{3}\left(\mathrm{NO}_{3}\right)_{2} \cdot \mathrm{H}_{2} \mathrm{O}(\mathrm{s})$. The purity of the compound was higher than $99.90 \%$ mass fraction (analytical uncertainty in mass fraction $\leqslant 0.20 \%$ ).

\subsection{Adiabatic calorimetry}

A high-precision automatic adiabatic calorimeter was used to measure the heat capacities over the temperature range $78 \mathrm{~K} \leqslant T \leqslant 371 \mathrm{~K}$. The calorimeter was fabricated in the Thermochemistry Laboratory of Dalian Institute of Chemical Physics, Chinese Academy of Sciences. The principle and structure of the adiabatic calorimeter were described in detail elsewhere. ${ }^{67}$ Briefly, the calorimeter comprised a sample cell, a platinum re- sistance thermometer, an electric heater, inner and outer adiabatic shields, two sets of six-junction chromel-constant thermopiles installed between the calorimetric cell and the inner shield and between the inner and outer shields, respectively, and a high vacuum can. The miniature platinum resistance thermometer (IPRT No.2, Shanghai Institute of Industrial Automatic Meters, $16 \mathrm{~mm}$ length, $1.6 \mathrm{~mm}$ diameter, and a nominal resistance of $100 \Omega$ ) was used to measure the temperature of the sample. The thermometer was calibrated on the basis of ITS-90 by the Station of Low Temperature Metrology and Measurements, Academia Sinica, China. The electrical energy introduced into the sample cell and the equilibrium temperature of the cell after the energy input were automatically recorded with the Data Acquisition/Switch Unit (model 34970A, Agilent, USA), and processed online by a computer. To verify the accuracy of the calorimeter, the heat capacity of the reference standard material $\left(\alpha-\mathrm{Al}_{2} \mathrm{O}_{3}\right)$ was measured over the temperature range $78 \mathrm{~K} \leqslant T \leqslant 373 \mathrm{~K}$. The sample mass used was $1.6382 \mathrm{~g}$, which was equivalent to $0.0161 \mathrm{~mol}$ based on its molar mass, $M\left(\mathrm{Al}_{2} \mathrm{O}_{3}\right)=101.9613 \mathrm{~g} \cdot \mathrm{mol}^{-1}$. The experimental molar heat capacities of $\alpha-\mathrm{Al}_{2} \mathrm{O}_{3}$ were fitted by the least-squares method to a polynomial. Deviations of the experimental results from those of the smoothed curve lie within $\pm 0.2 \%$, while the uncertainty is within $0.3 \%$, when compared with the values given by the former National Bureau of Standards ${ }^{8}$ over the entire temperature range. Heat capacity measurements were continuously and automatically carried out by means of the standard method of intermittently heating the sample and alternately measuring the temperature. The heating rate and temperature increments were controlled at $0.1-0.4 \mathrm{~K} \cdot \mathrm{min}^{-1}$ and $1-3 \mathrm{~K}$, respectively. The heating duration was $10 \mathrm{~min}$, and the temperature drift rate of the sample cell measured during an equilibrium period was always kept within $10^{-3}-10^{-4} \mathrm{~K} \cdot \mathrm{min}^{-1}$ for acquisition of the heat capacity data. The data of heat capacities and corresponding equilibrium temperature have been corrected for heat exchange of the sample cell with its surroundings. ${ }^{6,7}$ The sample mass of $\mathrm{Zn}(\mathrm{Met})_{3}\left(\mathrm{NO}_{3}\right)_{2} \cdot \mathrm{H}_{2} \mathrm{O}$ (s) used for the calorimetric measurement is $3.8993 \mathrm{~g}$, which is equivalent to $0.00595 \mathrm{~mol}$ in terms of its molar mass, $M=655.0560 \mathrm{~g} \cdot \mathrm{mol}^{-1}$.

\subsection{Isoperibol solution-reaction calorimetry}

The isoperibol solution-reaction calorimeter is primarily consisted of a precision temperature controlling system, an electric energy calibration system, a calorimetric body, an electric stirring system, a thermostatic bath made from transparent silicate glass, a precision temperature measuring system and a data acquisition system. The principle and structure of the calorimeter have been described in detail elsewhere. ${ }^{9}$ The reliability of the calorimeter was verified initially by measuring the dissolution enthalpies of $\mathrm{KCl}$ (calorimetrical primary standard) in doubly distilled water at $T=298.15 \mathrm{~K}$. ${ }^{9}$ The mean dissolution enthalpy was $(17.547 \pm 0.013) \mathrm{kJ} \cdot \mathrm{mol}^{-1}$ for $\mathrm{KCl}$, which compares well with the corresponding published data, $(17.536 \pm 0.003) \mathrm{kJ} \cdot$ $\mathrm{mol}^{-1} \cdot{ }^{10} \mathrm{In}$ all dissolution experiments, $100 \mathrm{~mL}$ of $2 \mathrm{~mol} \cdot \mathrm{L}^{-1}$ 
$\mathrm{HCl}$ was chosen as the calorimetric solvent for measuring the dissolution enthalpies of the mixtures $\left\{\mathrm{ZnSO}_{4} \cdot 7 \mathrm{H}_{2} \mathrm{O}(\mathrm{s})+\right.$ $\left.2 \mathrm{NaNO}_{3}(\mathrm{~s})+3 \mathrm{Met}(\mathrm{s})\right\}$ and $\left\{\mathrm{Zn}(\mathrm{Met})_{3}\left(\mathrm{NO}_{3}\right)_{2} \cdot \mathrm{H}_{2} \mathrm{O}(\mathrm{s})+\mathrm{Na}_{2} \mathrm{SO}_{4}\right.$ (s) $\}$. The solid samples, $\mathrm{ZnSO}_{4} \cdot 7 \mathrm{H}_{2} \mathrm{O}(\mathrm{s}), \mathrm{NaNO}_{3}(\mathrm{~s})$, and Met (s), were ground in an agate mortar into a fine powder. The solid compounds were weighed on parchment paper separately to avoid mixing before dissolution. The mixture of $\sim 0.288 \mathrm{~g}$ of $\mathrm{ZnSO}_{4} \cdot 7 \mathrm{H}_{2} \mathrm{O}(\mathrm{s}), \sim 0.171 \mathrm{~g}$ of $\mathrm{NaNO}_{3}$ (s), and $\sim 0.450 \mathrm{~g}$ of Met (s) at a mole ratio of $n\left(\mathrm{ZnSO}_{4} \cdot 7 \mathrm{H}_{2} \mathrm{O}\right): n\left(\mathrm{NaNO}_{3}\right): n(\mathrm{Met})=1: 2: 3$ was dissolved in $100 \mathrm{~mL}$ of $2 \mathrm{~mol} \cdot \mathrm{L}^{-1} \mathrm{HCl}$ solution at $T=$ $298.15 \mathrm{~K}$. The final solution obtained was designated as solution A. The solids, $\mathrm{Zn}(\mathrm{Met})_{3}\left(\mathrm{NO}_{3}\right)_{2} \cdot \mathrm{H}_{2} \mathrm{O}(\mathrm{s})$ and $\mathrm{Na}_{2} \mathrm{SO}_{4}(\mathrm{~s})$, were ground into a fine powder and dried in a vacuum drying oven in order to remove additional adsorbed water. The solid compounds were weighed on parchment paper separately to avoid mixing before dissolution. The dissolution enthalpy of the mixture of $\sim 0.65 \mathrm{~g}$ of $\mathrm{Zn}(\mathrm{Met})_{3}\left(\mathrm{NO}_{3}\right)_{2} \cdot \mathrm{H}_{2} \mathrm{O}(\mathrm{s})$ and $\sim 0.14 \mathrm{~g}$ of $\mathrm{Na}_{2} \mathrm{SO}_{4}$ (s) at a mole ratio of $n\left(\mathrm{Zn}(\mathrm{Met})_{3}\left(\mathrm{NO}_{3}\right)_{2} \cdot \mathrm{H}_{2} \mathrm{O}\right)$ : $n\left(\mathrm{Na}_{2} \mathrm{SO}_{4}\right)=1: 1$ in $100 \mathrm{~mL}$ of $2 \mathrm{~mol} \cdot \mathrm{L}^{-1} \mathrm{HCl}$ solution was determined under the same conditions as mentioned above. The final solution obtained was named as solution $\mathrm{A}^{\prime}$. Finally, the $\mathrm{UV} / \mathrm{Vis}$ spectra and the data of the refractive indices were used to confirm whether solution A was in the same thermodynamic state as that of solution $\mathrm{A}^{\prime}$. The results indicate that chemical components and physicochemical properties of solution $\mathrm{A}$ are consistent with those of solution $\mathrm{A}^{\prime}$.

\section{Results and discussion}

\subsection{Low-temperature heat capacities}

The structure of the coordination compound is shown to be stable over the temperature range $78-325 \mathrm{~K}$, as shown in Table 1 and Fig.1. No phase change, association nor thermal decomposition is seen to occur. However, at temperatures above $325 \mathrm{~K}$, the heat capacity curve rises steeply. The phenomenon is associated with the dehydration or thermal decomposition of the compound, as shown by TG analysis. ${ }^{4}$ In addition, the initial dehydration temperature $\left(T_{\mathrm{D}}\right)$ has been obtained by analysis of the heat capacity curve. Two sections of the heat capacity curves, i.e., 78-325 $\mathrm{K}$ and $326-371 \mathrm{~K}$ are extrapolated linearly. The intersection point of these two straight lines is the initial decomposition temperature, $T_{\mathrm{D}}=325.10 \mathrm{~K}$ (Fig.1). TG analysis shows the initial dehydration temperature of $323.15 \mathrm{~K}$, the final dehydration temperature of $458.15 \mathrm{~K}$ and the mass loss of $2.79 \%$. The mass loss is identical with the percentage of the water molecule in the coordination compound (the theoretical mass loss during dehydration is $2.75 \%$ ). The initial dehydration temperature obtained from TG analysis is in agreement with that from the heat capacity curve. The main reason for the difference $(1.90 \mathrm{~K})$ between the two results is that the sample surface adsorbed moisture from the air during TG measurement. The surface adsorbed water removed prior to crystal water in the sample, which reduces the initial dehydration temperature and increases the actual mass loss of the sample. Howev-
Table 1 Experimental molar heat capacities of the compound $\mathrm{Zn}(\mathrm{Met})_{3}\left(\mathrm{NO}_{3}\right)_{2} \cdot \mathrm{H}_{2} \mathrm{O}(\mathrm{s})\left(\right.$ molar mass $\left.M=655.056 \mathrm{~g} \cdot \mathrm{mol}^{-1}\right)$

\begin{tabular}{|c|c|c|c|c|c|}
\hline$T / \mathrm{K}$ & $\frac{C_{p, \mathrm{~m}}}{\left(\mathrm{~J} \cdot \mathrm{K}^{-1} \cdot \mathrm{mol}^{-1}\right)}$ & $T / \mathrm{K}$ & $\frac{C_{p, \mathrm{~m}}}{\left(\mathrm{~J} \cdot \mathrm{K}^{-1} \cdot \mathrm{mol}^{-1}\right)}$ & $T / \mathrm{K}$ & $\frac{C_{p, \mathrm{~m}}}{\left(\mathrm{~J} \cdot \mathrm{K}^{-1} \cdot \mathrm{mol}^{-1}\right)}$ \\
\hline 78.110 & 138.751 & 156.622 & 269.588 & 284.954 & 440.420 \\
\hline 79.528 & 141.929 & 158.151 & 272.076 & 288.070 & 444.685 \\
\hline 81.525 & 147.193 & 159.834 & 274.652 & 291.051 & 452.028 \\
\hline 84.113 & 152.236 & 161.517 & 276.073 & 294.099 & 458.662 \\
\hline 86.560 & 156.411 & 163.046 & 278.383 & 296.945 & 466.005 \\
\hline 88.931 & 161.564 & 164.653 & 280.959 & 299.722 & 471.691 \\
\hline 91.302 & 166.805 & 166.259 & 282.381 & 302.501 & 477.850 \\
\hline 93.521 & 171.957 & 167.865 & 283.625 & 305.074 & 484.483 \\
\hline 95.815 & 177.021 & 169.395 & 285.401 & 307.513 & 490.406 \\
\hline 97.957 & 181.463 & 172.454 & 289.044 & 309.749 & 495.617 \\
\hline 100.098 & 185.372 & 176.661 & 294.285 & 311.984 & 505.567 \\
\hline 102.239 & 189.902 & 180.638 & 298.371 & 314.288 & 511.726 \\
\hline 104.305 & 194.611 & 184.615 & 302.014 & 316.319 & 517.649 \\
\hline 106.370 & 197.631 & 188.593 & 306.633 & 319.165 & 526.177 \\
\hline 108.435 & 201.273 & 192.340 & 310.719 & 321.536 & 540.628 \\
\hline 110.424 & 203.849 & 196.241 & 315.694 & 323.975 & 554.368 \\
\hline 112.336 & 206.871 & 199.989 & 319.692 & 326.414 & 571.187 \\
\hline 114.325 & 210.335 & 203.737 & 322.890 & 328.853 & 586.823 \\
\hline 116.237 & 213.977 & 207.485 & 327.865 & 331.224 & 611.934 \\
\hline 118.073 & 217.264 & 211.079 & 331.329 & 333.663 & 635.149 \\
\hline 119.985 & 220.284 & 214.751 & 334.705 & 335.981 & 661.016 \\
\hline 121.897 & 223.394 & 218.422 & 338.969 & 338.352 & 684.927 \\
\hline 123.733 & 225.703 & 221.941 & 343.322 & 340.645 & 702.932 \\
\hline 125.568 & 228.368 & 225.459 & 347.498 & 342.941 & 724.312 \\
\hline 127.404 & 230.678 & 228.977 & 351.939 & 345.236 & 744.004 \\
\hline 129.087 & 232.544 & 232.419 & 356.204 & 347.531 & 760.601 \\
\hline 130.922 & 235.386 & 235.861 & 360.290 & 349.749 & 774.386 \\
\hline 132.758 & 236.808 & 239.303 & 364.466 & 351.891 & 787.607 \\
\hline 134.517 & 240.095 & 242.515 & 368.463 & 353.955 & 798.579 \\
\hline 136.276 & 241.960 & 245.881 & 372.735 & 356.021 & 810.675 \\
\hline 138.035 & 244.092 & 249.169 & 377.791 & 358.009 & 821.928 \\
\hline 139.795 & 246.402 & 252.611 & 382.588 & 359.845 & 830.367 \\
\hline 141.554 & 248.534 & 255.977 & 387.563 & 361.604 & 838.807 \\
\hline 143.159 & 251.110 & 259.189 & 391.472 & 363.287 & 847.587 \\
\hline 144.919 & 252.443 & 262.555 & 395.469 & 364.816 & 853.509 \\
\hline 146.602 & 254.575 & 265.844 & 401.895 & 366.040 & 858.898 \\
\hline 148.285 & 257.240 & 269.132 & 407.447 & 367.417 & 863.636 \\
\hline 149.891 & 260.349 & 272.345 & 413.740 & 368.411 & 867.723 \\
\hline 151.573 & 262.837 & 275.557 & 420.477 & 370.017 & 872.935 \\
\hline 153.256 & 264.880 & 278.693 & 427.658 & 371.701 & 877.139 \\
\hline 154.939 & 267.012 & 281.829 & 434.987 & & \\
\hline
\end{tabular}

er, during the adiabatic calorimetric measurements, when the sample is put into the sample cell, the air pressure within the sample cell is vacuumed to below $100 \mathrm{~Pa}$ with a vacuum pump to prevent moisture from being adsorbed on the surface of the sample. Then, about $100 \mathrm{kPa}$ of high purity helium is filled in the sample cell to increase the rate of heat conduction of sample cell during low temperature heat capacity measurements and also to reduce the time to reach thermal equilibrium. The 


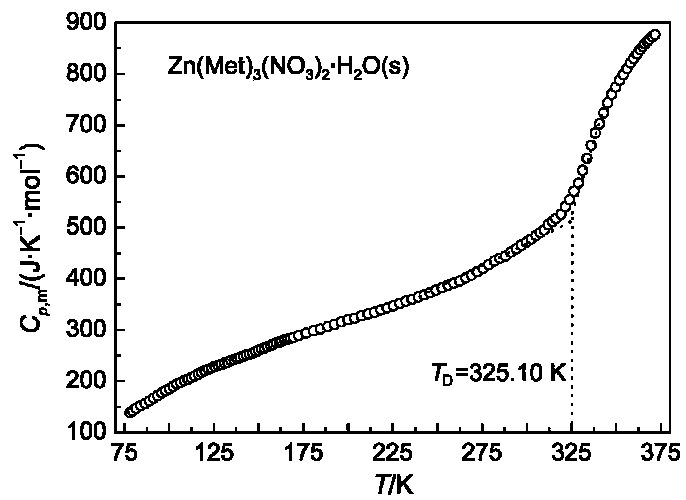

Fig.1 Plot of heat capacity $\left(C_{p, \mathrm{~m}}\right)$ against temperature $(T)$ for $\mathrm{Zn}(\mathrm{Met})_{3}\left(\mathrm{NO}_{3}\right)_{2} \cdot \mathrm{H}_{2} \mathrm{O}(\mathrm{s})$

sample cell was sealed by soldering. In the temperature range of $78-325 \mathrm{~K}$, the rise in heat capacity curve is steady. However, at $326-371 \mathrm{~K}$, the curve rises very steeply, indicating that the compound is decomposed into another substance. The experimental points in the temperature range of $78-325 \mathrm{~K}$ are fitted by the least-squares method, and a polynomial equation of experimental molar heat capacities $\left(C_{p, \mathrm{~m}}\right) /\left(\mathrm{J} \cdot \mathrm{K}^{-1} \cdot \mathrm{mol}^{-1}\right)$ versus the reduced temperature $(X), X=f(T)=\left[T-\left(T_{1}+T_{2}\right) / 2\right] /\left[\left(T_{1}-T_{2}\right) / 2\right]$ where $T_{1}=325 \mathrm{~K}$ and $T_{2}=78 \mathrm{~K}$, is obtained (Eq.(1)).

$$
C_{p, \mathrm{~m}}=320.683+137.917 X+7.567 X^{2}+45.893 X^{3}+
$$

$$
9.619 X^{4}+23.068 X^{6}+7.318 X^{6}
$$

where $X=(T-201.5) / 123.5$. The standard deviations of experimental molar heat capacities from the smoothed heat capacities calculated by the polynomial equation are within $\pm 0.3 \%$ except for some points around the lower and upper temperature. In addition, Fig. 1 shows that a slow process of dehydration occurs after $325 \mathrm{~K}$ rather than an obvious peak of dehydration. There are two possible reasons for this phenomenon. On the one hand, the crystal water possesses a large percentage in the compound; while on the other hand, the mass of the sample is large. Since the sample cell is sealed during the entire calorimetric experiment, once the dehydration occurs, the speed of dehydration should accelerate with the temperature rising. Meanwhile, the rate of the dehydration is also inhibited as a result of the rapid increase of vapor pressure of the water in the sample cell.
Table 2 Smoothed heat capacities and thermodynamic functions

\begin{tabular}{|c|c|c|c|c|}
\hline$T / \mathrm{K}$ & $\frac{C_{p, \mathrm{~m}}}{\left(\mathrm{~J} \cdot \mathrm{K}^{-1} \cdot \mathrm{mol}^{-1}\right)}$ & $\frac{\left[H_{l}-H_{298.15 \mathrm{~K}}\right]}{\left(\mathrm{J} \cdot \mathrm{mol}^{-1}\right)}$ & $\frac{\left[S_{I}-S_{298.15 \mathrm{~K}}\right]}{\left(\mathrm{J} \cdot \mathrm{K}^{-1} \cdot \mathrm{mol}^{-1}\right)}$ & $\frac{\left[G_{l}-G_{298.15 \mathrm{~K}}\right]}{\left(\mathrm{J} \cdot \mathrm{mol}^{-1}\right)}$ \\
\hline 298.15 & 467.307 & 0 & 0 & 0 \\
\hline 300 & 472.001 & 868.766 & 2.9039 & -2.42011 \\
\hline 305 & 485.409 & 3261.59 & 10.811 & -35.5119 \\
\hline 310 & 499.978 & 5724.24 & 18.815 & -108.306 \\
\hline 315 & 515.842 & 8262.82 & 26.935 & -221.735 \\
\hline 320 & 533.151 & 10884.1 & 35.189 & -376.381 \\
\hline 325 & 552.066 & 13595.8 & 43.595 & -572.405 \\
\hline
\end{tabular}
of the compound $\mathrm{Zn}(\mathrm{Met})_{3}\left(\mathrm{NO}_{3}\right)_{2} \cdot \mathrm{H}_{2} \mathrm{O}(\mathrm{s})$

\subsection{Smoothed heat capacities and thermodynamic functions of the sample}

The smoothed values of molar heat capacities and thermodynamic functions of the compound, $\mathrm{Zn}(\mathrm{Met})_{3}\left(\mathrm{NO}_{3}\right)_{2} \cdot \mathrm{H}_{2} \mathrm{O}(\mathrm{s})$ are derived according to the following thermodynamic equations (Eqs.(2)-(4)).

$$
\begin{aligned}
& H_{T}-H_{298.15 \mathrm{~K}}=\int_{298.15}^{T} C_{p, \mathrm{~m}} \mathrm{~d} T \\
& S_{T}-S_{298.15 \mathrm{~K}}=\int_{228.15}^{T} C_{p, \mathrm{~m}} T^{-1} \mathrm{~d} T \\
& G_{T}-G_{298.15 \mathrm{~K}}=\int_{298.15}^{T} C_{p, \mathrm{~m}} \mathrm{~d} T-T \int_{298.15}^{T} C_{p, \mathrm{~m}} T^{-1} \mathrm{~d} T
\end{aligned}
$$

The fitted polynomial values of the molar heat capacities and fundamental thermodynamic functions of the sample relative to the standard reference temperature, $298.15 \mathrm{~K}$ at an interval of $5 \mathrm{~K}$, are given in Table 2.

\subsection{Dissolution enthalpies of the mixtures $\mathrm{ZnSO}_{4}$.$$
\left.7 \mathrm{H}_{2} \mathrm{O}(\mathrm{s})+2 \mathrm{NaNO}_{3}(\mathrm{~s})+3 \mathrm{Met}(\mathrm{s})\right\} \text { and }
$$$$
\left\{\mathrm{Zn}(\mathrm{Met})_{3}\left(\mathrm{NO}_{3}\right)_{2} \cdot \mathrm{H}_{2} \mathrm{O}(\mathrm{s})+\mathrm{Na}_{2} \mathrm{SO}_{4}(\mathrm{~s})\right\}
$$

The compound, $\mathrm{Zn}(\mathrm{Met})_{3}\left(\mathrm{NO}_{3}\right)_{2} \cdot \mathrm{H}_{2} \mathrm{O}(\mathrm{s})$, is one of the products in the following reaction (Eq.(5)).

$$
\begin{aligned}
& \mathrm{ZnSO}_{4} \cdot 7 \mathrm{H}_{2} \mathrm{O}(\mathrm{s})+2 \mathrm{NaNO}_{3}(\mathrm{~s})+3 \mathrm{Met}(\mathrm{s})= \\
& \mathrm{Zn}(\mathrm{Met})_{3}\left(\mathrm{NO}_{3}\right)_{2} \cdot \mathrm{H}_{2} \mathrm{O}(\mathrm{s})+\mathrm{Na}_{2} \mathrm{SO}_{4}(\mathrm{~s})+6 \mathrm{H}_{2} \mathrm{O}(\mathrm{l})
\end{aligned}
$$

The enthalpy change of the proposed reaction above and standard molar enthalpy of formation of the compound $\mathrm{Zn}(\mathrm{Met})_{3}\left(\mathrm{NO}_{3}\right)_{2}$. $\mathrm{H}_{2} \mathrm{O}(\mathrm{s})$ are determined by a designed thermochemical cycle using the experimental data of isoperibol calorimetry and other

\begin{tabular}{|c|c|c|c|c|c|c|c|c|}
\hline No. & $W_{\mathrm{ZnSO}_{4} \cdot \mathrm{H}_{2} \mathrm{O}} / \mathrm{g}$ & $W_{\mathrm{NaNO}_{3}} / \mathrm{g}$ & $W_{\mathrm{Me}} / \mathrm{g}$ & $\Delta E_{\mathrm{e}} / \mathrm{mV}$ & $\Delta E_{\mathrm{s}} / \mathrm{mV}$ & $t_{\mathrm{e}} / \mathrm{s}$ & $Q_{\mathrm{s}} / \mathrm{J}$ & $\Delta_{\mathrm{d}} H_{\mathrm{m}, 1}^{0} /\left(\mathrm{kJ} \cdot \mathrm{mol}^{-1}\right)$ \\
\hline 1 & 0.2876 & 0.1700 & 0.4477 & 3.2295 & 3.2536 & 623.46 & 64.405 & 64.397 \\
\hline 2 & 0.2885 & 0.1705 & 0.4491 & 3.2272 & 3.2719 & 634.46 & 65.129 & 64.917 \\
\hline 3 & 0.2892 & 0.1710 & 0.4502 & 3.2612 & 3.2769 & 628.26 & 65.072 & 64.704 \\
\hline 4 & 0.2891 & 0.1709 & 0.4500 & 3.2185 & 3.2758 & 634.11 & 64.840 & 64.495 \\
\hline 5 & 0.2886 & 0.1706 & 0.4493 & 3.2272 & 3.2659 & 629.85 & 64.773 & 64.540 \\
\hline
\end{tabular}
thermodynamic data.

If " $\mathrm{s}$ " =calorimetric solvent, $2 \mathrm{~mol} \cdot \mathrm{L}^{-1} \mathrm{HCl}(\mathrm{aq})$, the dissolution process of the mixture of reactants in reaction (5) is expressed as $\left\{\mathrm{ZnSO}_{4} \cdot 7 \mathrm{H}_{2} \mathrm{O}(\mathrm{s})+2 \mathrm{NaNO}_{3}(\mathrm{~s})+3 \mathrm{Met}(\mathrm{s})\right\}+$ "s" to give solution A.

Table 3 Dissolution enthalpy of $\left\{\mathrm{ZnSO}_{4} \cdot 7 \mathrm{H}_{2} \mathrm{O}(\mathrm{s})+2 \mathrm{NaNO}_{3}(\mathrm{~s})+3 \mathrm{Met}(\mathrm{s})\right\}$ mixture at a mole ratio of $n\left(\mathrm{ZnSO}_{4} \cdot 7 \mathrm{H}_{2} \mathrm{O}\right): n\left(\mathrm{NaNO}_{3}\right): n(\mathrm{Met})=1: 2: 3 \mathrm{in} 100 \mathrm{~mL} 2 \mathrm{~mol} \cdot \mathrm{L}^{-1} \mathrm{HCl}$ solution at $298.15 \mathrm{~K}$

$W$ : mass of the sample; $\Delta E_{\mathrm{e}}$ : voltage change during electric calibration; $\Delta E_{\mathrm{s}}$ : voltage change during dissolution of the sample; $t$ : heating time during electric calibration; $Q_{\mathrm{s}}$ : heat effect during dissolution of the sample; $\Delta_{\mathrm{d}} H_{\mathrm{m}, 1}^{0}$ : molar enthalpy of dissolution, $\Delta_{\mathrm{d}} H_{\mathrm{m}, l}^{0}=\left(\Delta E_{\mathrm{e}} / \Delta E_{\mathrm{s}}\right) \cdot I^{2} R t \cdot(M / W) ; R$ : the resistance of the heater in the reaction chamber $(R=1017.2 \Omega$ at $T=298.15 \mathrm{~K}) ;$ : the current through heater during electric calibration $(I=10.115 \mathrm{~mA})$; $M$ : molar weight of the sample. $I=10.115 \mathrm{~mA}, R=1017.2 \Omega$ 
Table 4 Dissolution enthalpy of $\left\{\mathrm{Zn}(\mathrm{Met})_{3}\left(\mathrm{NO}_{3}\right)_{2} \cdot \mathrm{H}_{2} \mathrm{O}(\mathrm{s})+\mathrm{Na}_{2} \mathrm{SO}_{4}(\mathrm{~s})\right\}$ mixture at a mole ratio of $n\left(\mathrm{Zn}(\mathrm{Met})_{3}\left(\mathrm{NO}_{3}\right)_{2} \cdot \mathrm{H}_{2} \mathrm{O}\right): n\left(\mathrm{Na}_{2} \mathrm{SO}_{4}\right)=1: 1$ in $100 \mathrm{~mL} 2 \mathrm{~mol} \cdot \mathrm{L}^{-1} \mathrm{HCl}$ solution at $298.15 \mathrm{~K}$

\begin{tabular}{|c|c|c|c|c|c|c|c|}
\hline No. & $W_{\mathrm{Zn}\left(\mathrm{Met}_{3}\right)_{3}\left(\mathrm{NO}_{3}\right)_{2} \mathrm{H}_{2} \mathrm{O}} / \mathrm{g}$ & $W_{\mathrm{Na}_{2} \mathrm{SO}_{4}} / \mathrm{g}$ & $\Delta E_{\mathrm{e}} / \mathrm{mV}$ & $\Delta E_{\mathrm{s}} / \mathrm{mV}$ & $t_{\mathrm{e}} / \mathrm{s}$ & $Q_{\mathrm{s}} / \mathrm{J}$ & $\Delta_{\mathrm{d}} H_{\mathrm{m}, 2}^{0} /\left(\mathrm{kJ} \cdot \mathrm{mol}^{-1}\right)$ \\
\hline 1 & 0.6551 & 0.1422 & 2.3646 & 2.4096 & 465.77 & 47.569 & 47.563 \\
\hline 2 & 0.6572 & 0.1426 & 2.5546 & 2.5750 & 463.97 & 47.905 & 47.749 \\
\hline 3 & 0.6588 & 0.1430 & 2.3228 & 2.3962 & 476.38 & 48.060 & 47.788 \\
\hline 4 & 0.6586 & 0.1429 & 2.4939 & 2.5367 & 467.75 & 47.859 & 47.604 \\
\hline 5 & 0.6574 & 0.1427 & 2.5255 & 2.5738 & 468.51 & 47.844 & 47.672 \\
\hline \multicolumn{8}{|c|}{$\Delta_{\mathrm{d}} H_{\mathrm{m}, 2}^{0}$ (avg.) $=(47.675 \pm 0.042) \mathrm{kJ} \cdot \mathrm{mol}^{-1}$} \\
\hline
\end{tabular}

Table 5 Reaction scheme used to determine the standard molar enthalpy of formation of $\mathrm{Zn}\left(\mathrm{Met}_{3}\left(\mathrm{NO}_{3}\right)_{2} \cdot \mathrm{H}_{2} \mathrm{O}(\mathrm{s})\right.$ at $298.15 \mathrm{~K}$

\begin{tabular}{|c|c|c|c|}
\hline No. & Reaction & $\left(\Delta_{\mathrm{f}} H_{\mathrm{m}}^{0}\right.$ or $\left.\Delta_{\mathrm{d}} H_{\mathrm{m}}^{0} \pm \sigma_{\mathrm{a}}\right) /\left(\mathrm{kJ} \cdot \mathrm{mol}^{-1}\right)$ & Enthalpy change of reaction \\
\hline 1 & $\left\{\mathrm{ZnSO}_{4} \cdot 7 \mathrm{H}_{2} \mathrm{O}(\mathrm{s})+2 \mathrm{NaNO}_{3}(\mathrm{~s})+3 \mathrm{Met}(\mathrm{s})\right\}+" \mathrm{~s} "=$ solution $\mathrm{A}$ & $(64.611 \pm 0.091)$ & $\Delta H_{1}$ \\
\hline 2 & $\left\{\mathrm{Zn}(\mathrm{Met})_{3}\left(\mathrm{NO}_{3}\right)_{2} \cdot \mathrm{H}_{2} \mathrm{O}(\mathrm{s})+\mathrm{Na}_{2} \mathrm{SO}_{4}(\mathrm{~s})\right\}+“ \mathrm{~s} "=$ solution $\mathrm{A}^{\prime}$ & $(47.675 \pm 0.042)$ & $\Delta H_{2}$ \\
\hline 3 & solution $\mathrm{A}^{\prime}+\left\{6 \mathrm{H}_{2} \mathrm{O}(\mathrm{l})\right\}=$ solution $\mathrm{A}$ & 0 & $\Delta H_{3}$ \\
\hline 4 & $\mathrm{Na}(\mathrm{s})+(1 / 2) \mathrm{N}_{2}(\mathrm{~g})+(3 / 2) \mathrm{O}_{2}(\mathrm{~g})=\mathrm{NaNO}_{3}(\mathrm{~s})$ & -466.24 & $\Delta H_{4}$ \\
\hline 5 & $\mathrm{Zn}(\mathrm{s})+\mathrm{S}(\mathrm{s})+(11 / 2) \mathrm{O}_{2}(\mathrm{~g})+7 \mathrm{H}_{2}(\mathrm{~g})=\mathrm{ZnSO}_{4} \cdot 7 \mathrm{H}_{2} \mathrm{O}(\mathrm{s})$ & -3077.75 & $\Delta H_{5}$ \\
\hline 6 & $5 \mathrm{C}(\mathrm{s})+1 / 2 \mathrm{~N}_{2}(\mathrm{~g})+\mathrm{O}_{2}(\mathrm{~g})+11 / 2 \mathrm{H}_{2}(\mathrm{~g})+\mathrm{S}(\mathrm{s})=\operatorname{Met}(\mathrm{s})$ & $-(577.50 \pm 0.70)$ & $\Delta H_{6}$ \\
\hline 7 & $2 \mathrm{Na}(\mathrm{s})+\mathrm{S}(\mathrm{s})+2 \mathrm{O}_{2}=\mathrm{Na}_{2} \mathrm{SO}_{4}(\mathrm{~s})$ & -1383.16 & $\Delta H_{7}$ \\
\hline 8 & $\mathrm{H}_{2}(\mathrm{~g})+(1 / 2) \mathrm{O}_{2}(\mathrm{~g})=\mathrm{H}_{2} \mathrm{O}(\mathrm{l})$ & $-(285.830 \pm 0.042)$ & $\Delta H_{8}$ \\
\hline 9 & $\mathrm{Zn}(\mathrm{s})+15 \mathrm{C}(\mathrm{s})+(35 / 2) \mathrm{H}_{2}(\mathrm{~g})+(13 / 2) \mathrm{O}_{2}(\mathrm{~g})+(3 / 2) \mathrm{N}_{2}(\mathrm{~g})=\mathrm{Zn}(\mathrm{Met})_{3}\left(\mathrm{NO}_{3}\right)_{2} \cdot \mathrm{H}_{2} \mathrm{O}(\mathrm{s})$ & $-(2292.44 \pm 11.12)$ & $\Delta H_{9}$ \\
\hline
\end{tabular}

The experimental results of the process are listed in Table 3. The dissolution process of the products, $\left\{\mathrm{Zn}(\mathrm{Met})_{3}\left(\mathrm{NO}_{3}\right)_{2} \cdot \mathrm{H}_{2} \mathrm{O}(\mathrm{s})+\right.$ $\left.\mathrm{Na}_{2} \mathrm{SO}_{4}(\mathrm{~s})\right\}$, in reaction (5) may be expressed as $\left\{\mathrm{Zn}(\mathrm{Met})_{3}\left(\mathrm{NO}_{3}\right)_{2}\right.$. $\left.\mathrm{H}_{2} \mathrm{O}(\mathrm{s})+\mathrm{Na}_{2} \mathrm{SO}_{4}(\mathrm{~s})\right\}+$ "s" to give solution $\mathrm{A}^{\prime}$. The results of the dissolution experiments are shown in Table 4. solution $\mathrm{A}^{\prime}+$ $\left\{6 \mathrm{H}_{2} \mathrm{O}(\mathrm{l})\right\}=$ solution $\mathrm{A}$. The enthalpy of dissolution of $\left\{6 \mathrm{H}_{2} \mathrm{O}(\mathrm{l})\right\}$ $\left(\Delta_{\mathrm{d}} H_{\mathrm{m}, 3}\right)$ as one of the products in reaction (5) in the solvent is within the range of experimental error, and may be omitted since the amount of $\mathrm{H}_{2} \mathrm{O}(\mathrm{l})$ is very small according to the stoichiometric number of $\mathrm{H}_{2} \mathrm{O}(\mathrm{l})$ in reaction (5), i.e., $\Delta_{\mathrm{d}} H_{\mathrm{m}, 3}=0 \mathrm{~kJ}$. $\mathrm{mol}^{-1}$. The enthalpy change of reaction (5), $\Delta_{\mathrm{r}} H_{\mathrm{m}, 5}$, can be calculated in accordance with the designed thermochemical cycle above and experimental results are listed in Tables 3 and 4 by the following equation: $\Delta_{\mathrm{r}} H_{\mathrm{m}, 10}=\Delta_{\mathrm{d}} H_{\mathrm{m}, 1}^{0}-\left(\Delta_{\mathrm{d}} H_{\mathrm{m}, 2}^{0}+\Delta_{\mathrm{d}} H_{\mathrm{m}, 3}^{0}\right)=(16.936 \pm$ $0.100) \mathrm{kJ} \cdot \mathrm{mol}^{-1}$.

In order to obtain the standard molar enthalpy of formation of the compound $\mathrm{Zn}(\mathrm{Met})_{3}\left(\mathrm{NO}_{3}\right)_{2} \cdot \mathrm{H}_{2} \mathrm{O}(\mathrm{s})$, a reaction scheme is arranged and given in Table 5. The enthalpy change of reaction (5) obtained from experimental values of the dissolution enthalpies of $\left\{\mathrm{ZnSO}_{4} \cdot 7 \mathrm{H}_{2} \mathrm{O}(\mathrm{s})+2 \mathrm{NaNO}_{3}(\mathrm{~s})+3 \mathrm{Met}(\mathrm{s})\right\}$ and $\left\{\mathrm{Zn}(\mathrm{Met})_{3}\left(\mathrm{NO}_{3}\right)_{2} \cdot \mathrm{H}_{2} \mathrm{O}(\mathrm{s})+\mathrm{Na}_{2} \mathrm{SO}_{4}(\mathrm{~s})\right\}$ in $100 \mathrm{~mL}$ of $2 \mathrm{~mol} \cdot \mathrm{L}^{-1}$ hydrochloric acid combined with some auxiliary thermodynamic data: ${ }^{11-14} \Delta_{\mathrm{f}} H_{\mathrm{m}}^{0}\left[\mathrm{Na}_{2} \mathrm{SO}_{4}, \mathrm{~s}\right]=-1383.16 \mathrm{~kJ} \cdot \mathrm{mol}^{-1},{ }^{11} \Delta_{\mathrm{f}} H_{\mathrm{m}}^{0}\left[\mathrm{NaNO}_{3}\right.$, $\mathrm{s}]=-466.24 \mathrm{~kJ} \cdot \mathrm{mol}^{-1},{ }^{12} \Delta_{\mathrm{f}} H_{\mathrm{m}}^{0}[\mathrm{Met}, \mathrm{s}]=-(577.50 \pm 0.70) \mathrm{kJ} \cdot \mathrm{mol}^{-1,},{ }^{13}$ $\Delta_{\mathrm{f}} H_{\mathrm{m}}^{0}\left[\mathrm{H}_{2} \mathrm{O}, 1,298.15 \mathrm{~K}\right]=-(285.83 \pm 0.04) \mathrm{kJ} \mathrm{mol}^{-1}{ }^{14}{ }^{14}$ have been used to calculate the standard molar enthalpy of formation of the compound $\mathrm{Zn}(\mathrm{Met})_{3}\left(\mathrm{NO}_{3}\right)_{2} \cdot \mathrm{H}_{2} \mathrm{O}(\mathrm{s})$ as follows:

$$
\begin{aligned}
\Delta_{\mathrm{f}} & H_{\mathrm{m}}^{0}\left[\mathrm{Zn}(\mathrm{Met})_{3}\left(\mathrm{NO}_{3}\right)_{2} \cdot \mathrm{H}_{2} \mathrm{O}, \mathrm{s}\right] \\
= & \Delta H_{9} \\
= & \Delta H_{1}-\left(\Delta H_{2}+\Delta H_{3}\right)+\left(2 \Delta H_{4}+\Delta H_{5}+3 \Delta H_{6}-\Delta H_{7}-6 \Delta H_{8}\right) \\
= & \Delta_{\mathrm{r}} H_{\mathrm{m}, 10}+2 \Delta_{\mathrm{f}} H_{\mathrm{m}}^{0}\left(\mathrm{NaNO}_{3}, \mathrm{~s}\right)+\Delta_{\mathrm{f}} H_{\mathrm{m}}^{0}\left(\mathrm{ZnSO}_{4} \cdot 7 \mathrm{H}_{2} \mathrm{O}, \mathrm{s}\right)+ \\
& 3 \Delta_{\mathrm{f}} H_{\mathrm{m}}^{0}(\mathrm{Met}, \mathrm{s})-\Delta_{\mathrm{f}} H_{\mathrm{m}}^{0}\left(\mathrm{Na}_{2} \mathrm{SO}_{4}, \mathrm{~s}\right)-6 \Delta_{\mathrm{f}} H_{\mathrm{m}}^{0}\left(\mathrm{H}_{2} \mathrm{O}, 1\right)
\end{aligned}
$$

$$
=-(2292.44 \pm 11.12) \mathrm{J} \cdot \mathrm{mol}^{-1}
$$

where $\Delta H_{1}$ to $\Delta H_{9}$ are the molar enthalpy changes of the corresponding reactions in Table 5. The results of UV/Vis spectrum and refractive index are important for checking the differences of the structure and composition for the two solutions. In the present study, all the reactants and products of reaction (5) can be easily dissolved in the selected solvent. The measured values of the refractive indices of solution $\mathrm{A}$ and solution $\mathrm{A}^{\prime}$ are $1.3882 \pm 0.0004$ and $1.3880 \pm 0.0005$, respectively. The results of $\mathrm{UV} / \mathrm{Vis}$ spectrum and the data of the refractive indices of solution A obtained are in agreement with those of solution $\mathrm{A}^{\prime}$. These results have demonstrated that the solutions $\mathrm{A}$ and $\mathrm{A}^{\prime}$ are same, and the designed Hess thermochemical cycle can be used reliably to derive the standard molar enthalpy of formation of the compound $\mathrm{Zn}(\mathrm{Met})_{3}\left(\mathrm{NO}_{3}\right)_{2} \cdot \mathrm{H}_{2} \mathrm{O}(\mathrm{s})$.

\section{Conclusions}

In summary, as for the compound $\mathrm{Zn}(\mathrm{Met})_{3}\left(\mathrm{NO}_{3}\right)_{2} \cdot \mathrm{H}_{2} \mathrm{O}(\mathrm{s})$, low temperature heat capacities have been measured by a precision automated adiabatic calorimeter over the temperature range 78-371 K. The thermodynamic functions of dehydration, the enthalpy, entropy and Gibbs free energy are obtained. In addition, the standard molar enthalpy of formation of the compound is also determined from the enthalpies of dissolution of the reactants and products and other thermodynamic data by a Hess thermochemical cycle.

\section{References}

(1) Mahmoud, M.; Abdel-Monem, S.; Paul, M. Zinc Methionine Complex for Acne Treatment. US Pat. US 40396 81.A, 197708-02. 
(2) Taguchi, S.; Inokuchi, M.; Nakajima, N.; Inomata, M.; Natitoh, Y. Antipruritic Drug and Antipruritic Composition. WO Pat. 10178, 1992-06-25.

(3) Harvey, H.; Ashmed, K. U. Preparation of Pharmaceutical Grade Amino Acid Chelates. US Pat. US 4830716, 1989-05-16.

(4) Gao, S. L.; Hou, Y. D.; Liu, J. R.; Ji, M.; Shi, Q. Z. Acta Chim. Sin. 2000, 58 (1), 65. [高胜利, 侯育冬, 刘建䜭, 冀 棉, 史启 祯. 化学学报, 2000, 58 (1),65.]

(5) Jiang, H. Y.; Ren, D. H.; Xie, H. F. Chin. J. Northwest Univ. (Nat.Sci.Ed .) 1986, 22, 1. [蒋海盈, 任德厚, 薛洪福. 西北 大学学报(自然科学版), 1986, 22, 1.]

(6) Tan, Z. C.; Sun, G. Y.; Sun, Y. J. Therm. Anal. 1995, 45, 59. doi: 10.1007/BF02548664

(7) Tan, Z. C.; Liu, B. P.; Zhang, J. B.; Sun, L. X. J. Comp. Appl. Chem. 2003, 20, 265.

(8) Ditmars, D. A.; Ishihara, S.; Chang, S. S.; Bernstein, G.; West, E. D. J. Res. Natl. Bur. Stand. 1982, 87, 159. doi: 10.6028/jres.
087.012

(9) Di, Y. Y.; Tan, Z. C.; Li, L. W.; Gao, S. L.; Sun, L. X. J. Chem. Thermodyn. 2006, 38, 884. doi: 10.1016/j.jct.2005.09.006

(10) Rychly, R.; Pekarek, V. J. Chem. Thermodyn. 1977, 9, 391. doi: 10.1016/0021-9614(77)90060-X

(11) Di, Y. Y.; Tan, Z. C.; Gao, S. L.; Wang, S. X. J. Chem. Eng. Data 2004, 49, 965. doi: 10.1021/je034264n

(12) Waeman, D. D.; Evans, W. H.; Parker, V. B.; Schumm, R. H.; Halow, I.; Bailey, S. M.; Churney, K. L.; Nuttall, R. L. Phys. Chem. Ref. Data 1982, 11, 138.

(13) Huffman, H. M.; Fox, S. M.; Ellis, E. L. J. Am. Chem. Soc. 1937, 59, 2144. doi: 10.1021/ja01290a018

(14) Dean, J. A. Lange's Handbook of Chemistry; 13th ed.; Science Press: Beijing, 1991; p 1491; translated by Shang, J. F., Cao, S. J., Xin, W. M., Zheng, F. Y., Lu, X. M., Lin, C. Q. [Dean, J. A. 兰氏化学手册. 第 13 版. 尚久方, 操时杰, 辛无名, 郑飞勇, 陆 晓明, 林长青, 译. 北京: 科学出版社, 1991: 1491.] 